\title{
Response of Arucula Cultivars to Saline Nutritive Solution Enriched With Potassium Nitrate
}

\author{
Francisco de Assis de Oliveira ${ }^{1}$, José de Souza Leite Neto ${ }^{1}$, Mychelle Karla Teixeira de Oliveira ${ }^{1}$, \\ Luan Alves Lima ${ }^{1}$, Luan Vitor Nascimento ${ }^{1}$, Carla Jamile Xavier Cordeiro ${ }^{1}$, Francisco Adênio Teixeira Alves ${ }^{1}$, \\ Francisco Aparecido da Costa Miranda ${ }^{1} \&$ Helena Maria de Morais Neta ${ }^{1}$ \\ ${ }^{1}$ Universidade Federal Rural do Semi-Árido, Mossoró, RN, Brazil \\ Correspondence: Francisco de Assis de Oliveira, Universidade Federal Rural do Semi-Árido, Mossoró, RN, \\ Brazil. E-mail: thikaoamigao@ufersa.edu.br
}

Received: February 13, 2018

doi:10.5539/jas.v10n11p269

\author{
Accepted: April 26, $2018 \quad$ Online Published: October 15, 2018 \\ URL: https://doi.org/10.5539/jas.v10n11p269
}

\begin{abstract}
The quality of water used to prepare a nutritive solution is a fundamental factor for plants to express their maximum yield potential, however, due to an emerging water scarcity, the use of saline water is turning into a challenge for producers and scientists. The present study was developed to evaluate the effect of potassium nitrate in two arucula cultivars fertigated with saline nutritive solutions in semi-hydroponic system. It was used a randomized block design, in factorial scheme $2 \times 4$, with two arucula cultivars (Cultivada and Folha Larga) and four nutritive solutions [S1-standard nutritive solution; S2-standard nutritive solution $+\mathrm{NaCl}\left(7.5 \mathrm{dS} \mathrm{m}^{-1}\right)$; S3-S2 $+50 \%$ of $\mathrm{KNO}_{3}$; $\mathrm{S} 4-100 \%$ of $\mathrm{KNO}_{3}$ ], with three replicates, with each experimental unit represented by a gutter of $1.5 \mathrm{~m}$ filled with coconut-fiber based substrate and 30 plants per replicate. Plants were collected 40 days after planting and evaluated for following variables: height, amount of leaves, leaf area, above ground fresh matter, above ground dry matter, leaf succulence, percentage of dry matter, and specific leaf area. Cultivada is more productive than Folha Larga, but presented higher sensibility to salinity. Increase of salinity in the water for preparation of nutritive solution negatively affects arucula cultivars' development in semi-hydroponic system. The use of potassium nitrate reduced the effects of salinity on the Folha Larga's development, but did not inhibit negative effects of salinity in any cultivar. Growth of arucula, Folha Larga, using saline water in semi-hydroponic system is feasible with addition of $50 \%$ of $\mathrm{KNO}_{3}$.
\end{abstract}

Keywords: Eruca sativa Miller, soilless growth, hydroponic

\section{Introduction}

Arucula (Eruca sativa Miller) is a leafy vegetable from Brassicaceae botanic family widely grown throughout the world, especially in Mediterranean countries, where it was originated (Morales \& Janick, 2002; Koukousaras et al., 2007). In Brazil is also known as mostarda persa, agrião mostarda or pinchão (Santos et al., 2012).

This leafy vegetable is consumed mainly in salads, characterizing itself for a strong bitter taste and its leaves rich in vitamin A, E, and C (Favell, 1998; Amorim et al., 2007), and also carotenoids, flavonoids and glucosinolates (Ku et al., 2016; Alruwaih \& Yaylayan, 2017) which may help to prevent cancers and cardiovascular diseases (Podsedek, 2007; Björkman et al., 2011).

This vegetable may be produced in open field, the traditional way, as well as in protected environment, technique that is significantly growing in Brazil (Machado et al., 2011), mainly in NFT (Nutrient Film Technique) hydroponic system (Luz et al., 2011; Silva et al., 2011; Jesus et al., 2015) or semi-hydroponic using inert substrate (Santos et al., 2012; Oliveira et al., 2013; Souza Neta et al., 2013).

In soilless cultivation (hydroponic or semi-hydroponic) the adequate concentration of nutrients in solution is fundamental to obtain high yields, especially nitrogen and potassium, the most absorbed nutrients in arucula crop (Cavarianni et al., 2008; Grangeiro et al., 2011).

Nitrogen, when applied in adequate quantities stimulates vegetative growth and expands the active photosynthetic area. Also it promotes growing of leaves with more attractive color and succulence, since it contributes to plant physiologic metabolism and is directly related to protein formation, chlorophyll molecule 
constituent, participates in cell respiration, multiplication and division, helping crops to express its potential yield (Nascimento et al., 2017).

Potassium plays role in plant cells and tissues on osmotic regulation, cations/anions balance, water-related plant relations, opening and closing of stomata, cell elongation, stabilization of $\mathrm{pH}$ in cytoplasm neutralizing organic and inorganic anions, enzymatic activation of most enzymes, protein synthesis, photosynthesis, phloem sugar transport, and seismonastic movements in plant (Kerbauy, 2004). Besides that, potassium acts in membrane potential balance and cell turgor, activating enzymes and regulating osmotic pressure. Increase in this nutrient concentration may modify $\mathrm{Na}^{+} / \mathrm{K}^{+}$ratio and, consequently, plant tolerance to salinity (Maathuis \& Sanders, 1996; Taiz \& Zaiger, 2013; Ahmad \& Maathuis, 2014).

Another major factor for soilless cultivation is the quality of water used to prepare nutritive solutions, mainly because of the concentration of dissolved salts, specially sodium chloride, as high concentration of $\mathrm{Na}^{+}$and $\mathrm{Cl}^{-}$ ions could make difficult the absorption of essential cations and anions, such as $\mathrm{K}^{+}$and $\mathrm{NO}_{3}{ }^{-}$(Paulus et al., 2012; Pérez-López et al., 2015; Cova et al., 2017).

In addition to reducing $\mathrm{K}^{+}$and $\mathrm{Ca}^{2+}$ absorption, high $\mathrm{Na}^{+}$concentration in vegetal tissue reduces photosynthetic capacity due to reduction of stomatal conductance. On the other side, high concentration of $\mathrm{Cl}^{-}$reduces the photosynthetic capacity due to chlorophyll degradation and in real quantum yield of electron transport (Tavakkoli et al., 2011).

Many studies were already made to evaluate the effect of salinity on arucula crop on NFT hydroponic system (Silva et al., 2011; Santos et al., 2012) or grown in substrate (Oliveira et al., 2013; Souza Neta et al., 2013), and the results showed that the use of saline water on nutritive solution preparation promotes significant reduction on crop yield, even though it may occur great variation on crop response according to the adopted system and cultivar.

This way, due to an emerging water scarcity, it comes the necessity to develop studies that make possible the use of saline water without affecting production and quality of plants. Facing what was exposed, this study aimed to evaluate the effect of potassium nitrate in two cultivars of arucula fertigated with saline nutritive solutions in semi-hydroponic system.

\section{Material and Methods}

The experiment was carried out from May to June 2017 in greenhouse from Departamento de Ciências Ambientais e Tecnológicas (DCAT) at Universidade Federal Rural do Semi-Árido (UFERSA), in Mossoró-RN, Brazil (5'12'04" S, 37 19'39" W and $18 \mathrm{~m}$ of altitude).

Climate in Mossoró, according to Köppen classification, is BSwh', or tropical semi-arid very hot and a rainy season during summer-winter, with average temperature of $27.4{ }^{\circ} \mathrm{C}$. Irregular precipitation with annual average of $673.9 \mathrm{~mm}$ and air relative humidity of $68.9 \%$ (Carmo Filho \& Oliveira, 1995).

Experimental design used was a randomized block, in factorial scheme $2 \times 4$, with three replicates, with a total of 24 experimental units, each unit represented by a gutter of $1.5 \mathrm{~m}$ with 30 plants. The first treatment factor was formed by two arucula cultivars (Cultivada and Folha Larga), while the second was four different nutritive solutions [S1-Standard nutritive solution; S2-Standard nutritive solution $+\mathrm{NaCl}\left(7.5 \mathrm{dS} \mathrm{m}^{-1}\right) ; \mathrm{S} 3-\mathrm{S} 2+50 \%$ of $\mathrm{KNO}_{3} ; \mathrm{S} 4-100 \%$ of $\mathrm{KNO}_{3}$.

To conduct the experiments a structure was built formed by 30 PVC gutters, with two used as borders in each block. Gutters were $1.5 \mathrm{~m}$ in length, $0.1 \mathrm{~m}$ in width, and $0.1 \mathrm{~m}$ in depth, disposed on top of asbestos roofing tiles suspended by wooden racks at $0.65 \mathrm{~m}$ over the ground.

Initially, gutters were filled uniformly with substrate (coconut-fiber), humidified with water from UFERSA water system. In each experimental plot (gutter) fifteen planting-holes were opened and planted, with five seeds per hole. Thinning to one plant per hole was done five days after planting, using more vigorous plants as criteria to decide which one to keep.

In the period between planting and thinning the irrigation was made manually with watering can, twice a day with water from the universities' system. After thinning, fertigation was initiated with nutritive solutions for each treatment through the irrigation system.

An independent system for each nutritive solution was built, with following items: 1 PVC reservoir $(60 \mathrm{~L})$, lateral tubes of $16 \mathrm{~mm}$, and emitter of $8 \mathrm{~mm}$ of intern diameter and $10 \mathrm{~cm}$ of length. Nutritive solution application was made via an electric pump (Metalcorte/Eberle, auto ventilated, model EBD 250076), activated by a single-phased motor $(210 \mathrm{~V}, 6 \mathrm{~Hz})$. 
Irrigation was controlled by a digital timer with capacity to hold eight daily on/off programs. After thinning until 20 days six irrigation of ten minutes each was made, between 7 am and $5 \mathrm{pm}$. At the $21^{\text {st }}$ day of nutritive solution application time of duration of each event increased to 20 minutes, since time and frequency helped drainage and storage of water in the substrate.

Nutritive solutions were prepared using water from a deep water well at the university, with the following physicochemical characteristics: $\mathrm{pH}=8.97 ; \mathrm{ECW}=0.62 \mathrm{dS} \mathrm{m}{ }^{-1} ; \mathrm{K}^{+}=2.07 \mathrm{mmol}_{\mathrm{c}} \mathrm{L}^{-1} ; \mathrm{Na}^{+}=0.91 \mathrm{mmol}_{\mathrm{c}} \mathrm{L}^{-1}$; $\mathrm{Ca}^{2+}=2.87 \mathrm{mmol}_{\mathrm{c}} \mathrm{L}^{-1} ; \mathrm{Mg}^{2+}=0.51 \mathrm{mmol}_{\mathrm{c}} \mathrm{L}^{-1} ; \mathrm{Cl}^{-}=3.91 \mathrm{mmol}_{\mathrm{c}} \mathrm{L}^{-1} ; \mathrm{CO}_{3}^{-2}=0.23 \mathrm{mmol}_{\mathrm{c}} \mathrm{L}^{-1} ; \mathrm{HCO}_{3}^{-}=1.78$ $\mathrm{mmol}_{\mathrm{c}} \mathrm{L}^{-1} ; \mathrm{SAR}=0.91 \mathrm{mmol}_{\mathrm{c}} \mathrm{L}^{-1} ; \mathrm{SAR}=0.70\left(\mathrm{mmol}_{\mathrm{c}} \mathrm{L}^{-1}\right)^{0,5}$.

Preparation and composition of nutritive solution was based on a recommendation proposed by Furlani et al (1999) for leafy vegetables hydroponic cultivation. After preparation, $\mathrm{pH}$ correction was made, maintaining it in between 5.5 and 6.5 using $\mathrm{NaOH}(1 \mathrm{M})$ and $\mathrm{HCl} 10 \%$ solutions. Fertilizer, quantities and their respective electrical conductivity used for nutritive solution preparation are shown in Table 1.

Table 1. Quantity of fertilizers, sodium chloride, and electrical conductivity of nutritive solutions

\begin{tabular}{lllll}
\hline \multirow{2}{*}{ Fertilizers } & \multicolumn{3}{c}{ Nutritive solutions $\left(\mathrm{g} 1.000 \mathrm{~L}^{-1}\right)$} \\
\cline { 2 - 5 } & $\mathrm{S} 1$ & $\mathrm{~S} 2$ & $\mathrm{~S} 3$ & $\mathrm{~S} 4$ \\
\hline Monoammonium phosphate & 150 & 150 & 150 & 150 \\
Calcium nitrate & 750 & 750 & 750 & 750 \\
Potassium nitrate & 500 & 500 & 750 & 1000 \\
Magnesium sulfate & 400 & 400 & 400 & 400 \\
Rexolin ${ }_{\mathrm{NaCl}}^{\mathrm{NaCl}}$ & 30 & 30 & 30 & 30 \\
$\mathrm{CE}(\mathrm{dS} \mathrm{m})^{-1}$ & 0 & 1900 & 1900 & 1900 \\
\hline
\end{tabular}

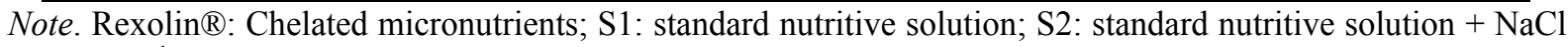
$\left(7.5 \mathrm{dS} \mathrm{m}{ }^{-1}\right) ; \mathrm{S} 3: \mathrm{S} 2+50 \%$ of $\mathrm{KNO}_{3} ; \mathrm{S} 4: \mathrm{S} 2+100 \%$ of $\mathrm{KNO}_{3}$. ${ }^{*}$ electrical conductivity after preparation of nutritive solutions. Rexolin $\AA$ : micronutrients $\left(11.6 \%\right.$ of potassium oxide $\left(\mathrm{K}_{2} \mathrm{O}\right), 1.28 \%$ of sulfur $(\mathrm{S}), 0.86 \%$ of magnesium $(\mathrm{Mg}), 2.1 \%$ of boron $(\mathrm{B}), 2.66 \%$ of iron $(\mathrm{Fe}), 0.36 \%$ of copper $(\mathrm{Cu}), 2.48 \%$ of manganese $(\mathrm{Mn})$, $0.036 \%$ of molybdenum (Mo), and $3.38 \%$ of zinc $(\mathrm{Zn})$.

Harvest was conducted at 40 days after planting, collecting 20 plants per plot. Plants were taken to Laboratório de Irrigação e Salinidade (lab) at UFERSA and evaluated for following variables:

Height - determined at harvest, using graduated rule $(\mathrm{cm})$, taking measurement between soil surface and the top of largest leaf.

Amount of leaves - measured after harvest, taking into consideration only those that had more than $70 \%$ of green color and larger than $3 \mathrm{~cm}$.

Leaf area-measured by disc method using a volumetric ring with intern diameter of $2.5 \mathrm{~mm}\left(4.9 \mathrm{~cm}^{2}\right)$, collecting randomly 20 leaf discs per plot. For this, discs and the rest of the leaf were separately stored in paper bags and dry out in forced air drying oven at a temperature of $65^{\circ} \mathrm{C}$ until reach a steady weight. Plant leaf area was calculated, using average values of discs, disc dry matter and leaf dry matter, as in Equation 1.

$$
\mathrm{LA}=\left(\frac{\mathrm{DA}}{\mathrm{LDM}}\right) /\left(\frac{\mathrm{DDM}}{20}\right)
$$

Where, LA: leaf area, $\mathrm{cm}^{2}$; DA: disc area, $\mathrm{cm}^{2}$; LDM: leaf dry matter, g; DDM: disc dry matter, g; 20: amount of leaves collected per plot.

Fresh matter-measured in lab, immediately after harvest, using a digital analytical scale $(0.01 \mathrm{~g})$.

Dry matter - measured also in analytical scale, after drying in forced air drying oven at temperature of $65^{\circ} \mathrm{C}$ and steady weight.

Specific leaf area — determined by the ratio between leaf area and leaf dry matter, as in Equation 2.

$$
\mathrm{SLA}=\frac{\mathrm{LA}}{\mathrm{LDM}}
$$

Where, SLA: specific leaf area, $\mathrm{cm}^{2} \mathrm{~g}^{-1} \mathrm{LDM}$; LA: leaf area, $\mathrm{cm}^{2}$; LDM: leaf dry matter, $\mathrm{g}$. 
Percentage of dry matter-measured by the ratio between dry matter and plant total fresh matter, expressing results in percentage as in Equation 3.

$$
\mathrm{PDM}=\left(\frac{\mathrm{TDM}}{\mathrm{TFM}}\right) \times 100
$$

Where, PDM: percentage of dry matter, \%; TDM: total dry matter, g; TFM: total fresh matter, g.

Leaf succulence was determined using the ratio between leaf water content and leaf area, as in Equation 4.

$$
\text { LS }=\frac{\text { LFM }- \text { LDM }}{\text { LA }}
$$

Where, LS: leaf succulence, $\mathrm{g} \mathrm{H}_{2} \mathrm{O} \mathrm{cm}^{2}$; LFM: leaf fresh matter, g; LDM: leaf dry matter, g; LA: leaf area, $\mathrm{cm}^{2}$ planta $^{-1}$.

For statistical analysis, obtained data were submitted to variance analysis through $\mathrm{F}$ test, unfolding factors according to the significance of interaction. Variables that presented significant response were analyzed with each other by Tukey test at 5\% of probability, using SISVAR 5.6 statistical software (Ferreira, 2014).

\section{Results and Discusion}

From statistical analysis of the data it was possible to verify that there was significant effect of significant interaction between both factors nutrient solution and cultivar for amount of leaf (AL), leaf area (LA), fresh matter (TFM), dry matter (LDM), specific leaf area (SLA), and percentage of dry matter (PDM) at a level of 5\% of probability.

Cultivars did not differ significantly for height and leaf succulence, with average values of $23.1 \mathrm{~cm}$ and $0.042 \mathrm{~g}$ $\mathrm{H}_{2} \mathrm{O} \mathrm{cm}$, respectively (Table 2). Plant height, in both cultivars, was reduced when used saline nutritive solution (S2), with average reduction of $24.29 \%$ in comparison to average plant height from standard solution. In addition, it is verified that the enrichment of nutritive solution with $\mathrm{KNO}_{3}$ was not efficient to inhibit salinity effect (Table 2).

Table 2. Average values for plant height and foliar succulence in arucula cultivars grown in coconut-fiber substrate and fertigated with saline nutritive solutions enriched with potassium nitrate

\begin{tabular}{lll}
\hline Nutritive solution & Height $(\mathrm{cm})$ & Foliar succulence $\left(\mathrm{g} \mathrm{H}_{2} \mathrm{O} \mathrm{cm}{ }^{2}\right)$ \\
\hline $\mathrm{S} 1: \mathrm{Standard}$ nutritive solution (SNS) & $28.80 \mathrm{a}^{*}$ & $0.0425 \mathrm{a}$ \\
$\mathrm{S} 2: \mathrm{SNS}+\mathrm{NaCl}\left(7.5 \mathrm{dS} \mathrm{m}^{-1}\right)$ & $21.80 \mathrm{~b}$ & $0.0425 \mathrm{a}$ \\
$\mathrm{S} 3: \mathrm{SNS}+\mathrm{NaCl}\left(7.5 \mathrm{dS} \mathrm{m}^{-1}\right)+50 \%$ of $\mathrm{KNO}_{3}$ & $22.19 \mathrm{~b}$ & $0.0435 \mathrm{a}$ \\
$\mathrm{S} 4: \mathrm{SNS}+\mathrm{NaCl}\left(7.5 \mathrm{dS} \mathrm{m}^{-1}\right)+100 \% \mathrm{KNO}_{3}$ & $19.61 \mathrm{~b}$ & $0.0375 \mathrm{~b}$ \\
\hline Cultivars & $22.49 \mathrm{a}$ & $0.043 \mathrm{a}$ \\
Cultivada & $23.70 \mathrm{a}$ & $0.040 \mathrm{a}$ \\
Folha Larga &
\end{tabular}

Note. *Average followed by same letter within columns did not differ from each other by Tukey test $(\mathrm{p}<0.05)$.

Even with the reduction in plant heights when increasing salinity, both cultivars got to commercial size, between 15 and $20 \mathrm{~cm}$ (Minami \& Tessariolo Neto, 1998).

Overall, one of the main effects of salinity is the reduction on plant growth due to a reduction in cell elongation (Shannon \& Grieve, 1998; Munns \& Tester, 2008). This way, as reported in this study, lack of salinity on nutritive solution (S1) resulted in higher plants (Table 2), and solutions where was used saline water there was a possible ions unbalance (Tester \& Davenport, 2003), even with addition of potassium nitrate.

Reduction in plant height on arucula crop was also observed by other authors (Silva et al., 2011; Souza Neta et al., 2013; Oliveira et al., 2013), in accordance with results found on effect of salinity.

Table 2 also notes that leaf succulence was not affected by the use of saline nutritive solution (S2), however, it was reduced in $11.76 \%$ when used saline nutritive solution enriched with $100 \%$ of $\mathrm{KNO}_{3}$.

For amount of leaves, it was verified that cultivars differ from each other only when plants where fertigated with saline nutritive solutions enriched with $\mathrm{KNO}_{3}$ ( $\mathrm{S} 3$ and S4), where Folha Larga was 14.11 and $14.17 \%$ superior to Cultivada, respectively (Figure 1A). 


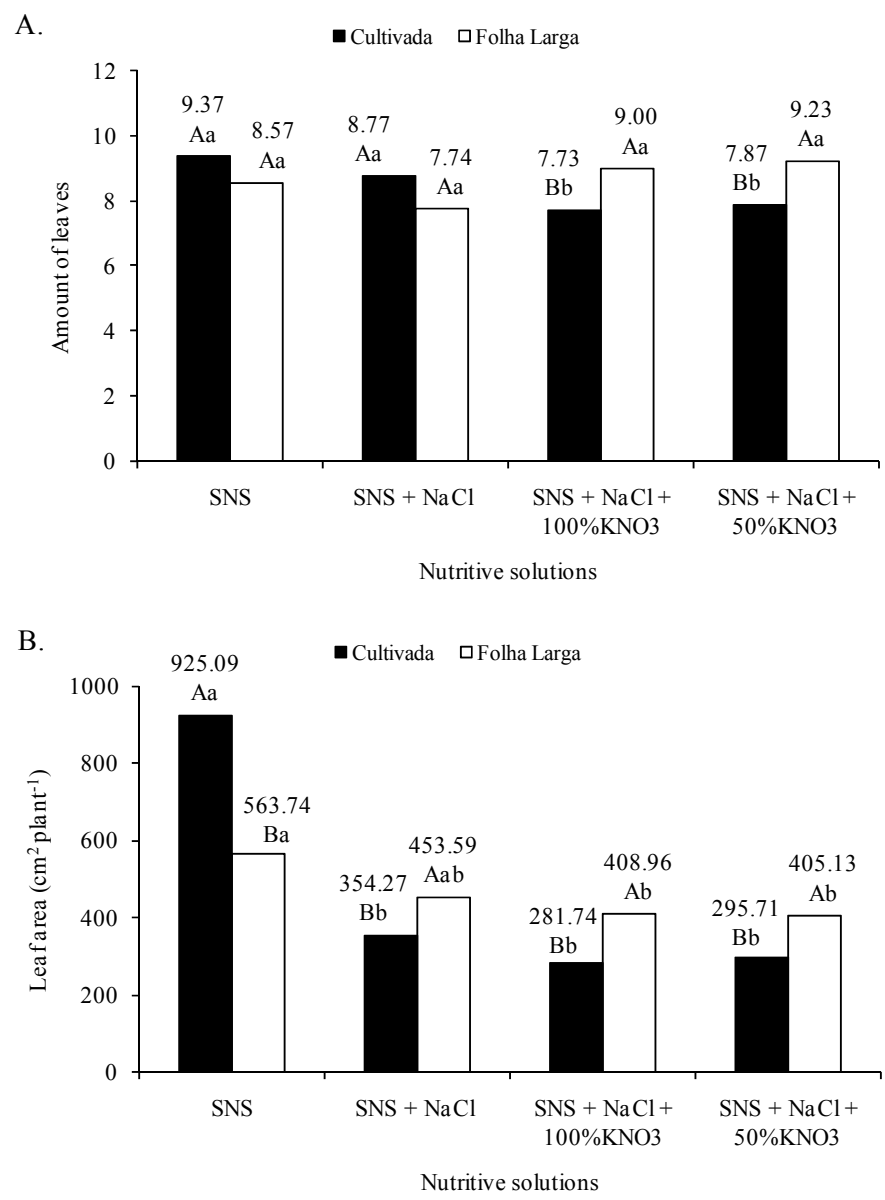

Figure 1. Amount of leaves (A) and leaf area (B) in arucula cultivars fertigated with saline nutritive solution and potassium nitrate [Averages followed by same letter, upper case (cultivars) and lower case (nutritive solutions) did not differ from each other by Tukey test at $5 \%$ of probability]

There was no significant effect of nutritive solutions observed on amount of leaves of Folha Larga cultivar, with average value of 8.63 leaves per plant. On the other side, the amount of leaves in Cultivada was reduced when used saline nutritive solution enriched with $\mathrm{KNO}_{3}$, showing reduction of 17.50 and $16.22 \%$ for S3 and S4, respectively (Figure 1A).

Amount of leaves is considered to be dependent of genetic material and variations may occur upon plant development (Costa et al., 2011). In this present work, AL could not be used as criteria for identification of tolerance to salinity, since cultivars used reduction of leaf area as strategic mechanism to saline stress, as observed in Figure 1A.

As for leaf area, it was observed significant difference between cultivars in all solutions studied, where Cultivada was $63.09 \%$ superior to Folha Larga; in contrast, Folha Larga was greater for other nutritive solutions, being superior in 28.05, 45.15, and 37.0\% in solutions S2, S3 and S4, respectively (Figure 2B).

Evaluating leaf area on nutritive solution in each cultivar it was verified a reduction on leaf expansion for Cultivada when fertigated with saline nutritive solution, aside from potassium nitrate addition, with reductions of $61.7,69.54$, and $68.03 \%$ on S2, S3, and S4 solutions, respectively, compared to plants irrigated with standard nutritive solution (S1). Similar results were observed for Folha Larga where saline nutritive solutions promoted loss of $19.54,34.13$, and $38.79 \%$ in S2, S3, and S4 solution, respectively (Figure 2B). Also, it was seen that addition of $\mathrm{KNO}_{3}$ did not decrease losses of leaf area due to saline stress.

Analyzing both cultivars together, it can be seen that Cultivada presented higher sensibility to salinity for leaf blade expansion, even though it presents greater leaf area in absence of saline stress. The lowest effect of salinity on leaf area in Folha Larga may be due to lack of consequences from saline stress on the amount of leaves in this 
cultivar. This behavior demonstrates that salinity effect was more severe in leaf blade expansion than in growing of new leaves (Oliveira et al., 2016).

Adverse effects of salinity in leaf area in arucula crop were reported by other authors (Souza Neta et al., 2013; Oliveira et al., 2013) and in other crops, such as lettuce (Dias et al., 2011), bell pepper (Nunes et al., 2013), and basil (Maia et al., 2017).

The lowest values of leaf area for plants under saline stress reflect the effect of the osmotic potential from soil solution, inhibiting plant water absorption (Tester \& Davenport, 2003). Decrease in leaf area is related to an unbalance in oxidation-reduction process (PP 155) due to $\mathrm{CO}_{2}$ restrict fixation, which reduces liquid assimilation rate and increases production of reactive oxygen species (ROS) via Mehler reaction (Miller et al., 2009; Parihar et al., 2015). This reduction may be related to a necessary energy translocation to activation and maintenance of metabolic activity associated to salinity tolerance, such as the integrity of membrane, organic solutes synthesis, ejection of ions, transport regulation, and distribution of ions in several organs and inside cells (Munns \& Tester, 2008).

There was significant difference for above ground fresh matter between cultivars only in standard nutritive solution (S1), where Cultivada was superior to Folha Larga in 26.35\% (Figure 2A).

A.

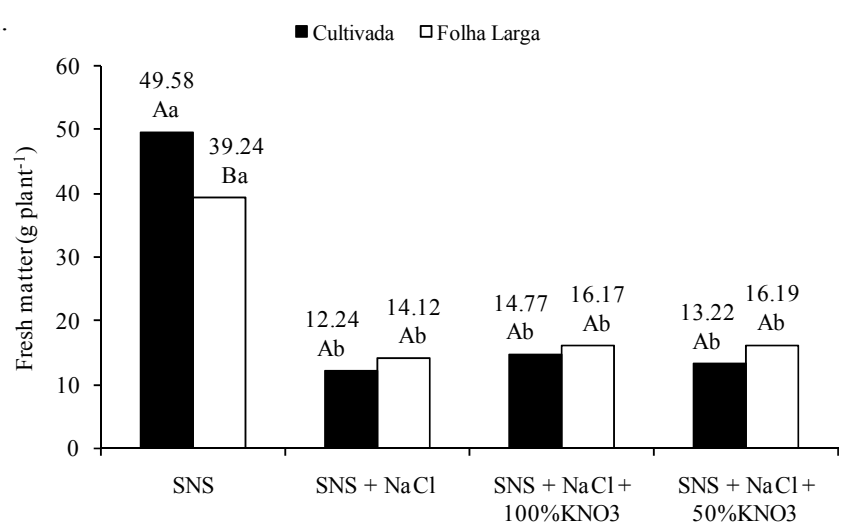

B.

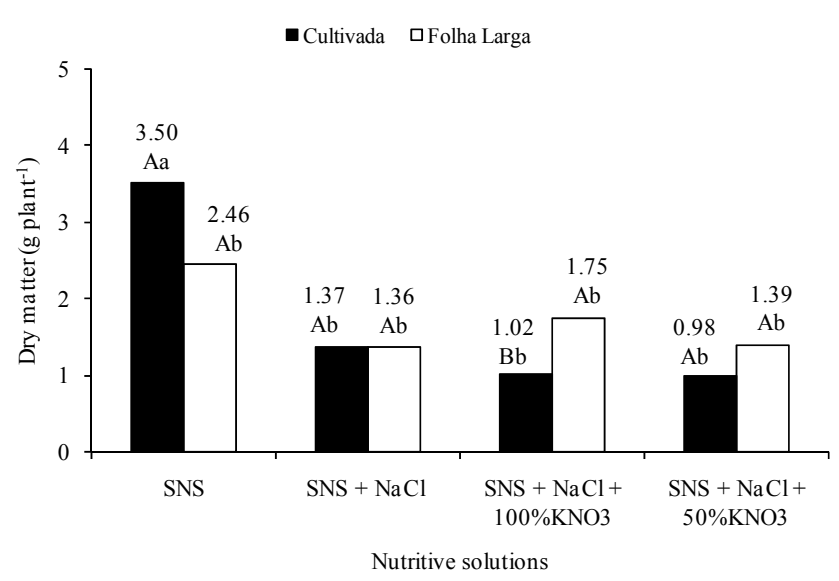

Figure 2. Above ground fresh matter (A) and above ground dry matter (B) in arucula cultivars fertigated with nutritive solution and potassium nitrate [Averages followed by same letter, upper case (cultivars) and lower case (nutritive solutions) did not differ from each other by Tukey test at 5\% of probability]

Analyzing the effect of nutritive solution on above ground fresh matter in each cultivar, it is verified that the use of saline nutritive solution (S2) promoted reduction in $71.28 \%$ and $64.02 \%$ for Cultivada and Folha Larga, respectively. Moreover, it may be observed that enrichment of nutritive solution with $\mathrm{KNO}_{3}$ was not efficient in reducing harmful effect of salinity on this variable (Figure 2A). 
The negative response of plants to above ground fresh matter with increase in salinity is due, especially, to decrease in stomata aperture as consequence of osmotic effect outside roots (Munns \& Tester, 2008). This way, plants metabolic activity is reduced and turns photosynthetic activity (Prado, 2008) and fresh matter production limited.

Negative effect of salinity on fresh matter of arucula was also reported in studies performed in substrates by other authors (Santos et al., 2012; Oliveira et al., 2013; Souza Neta et al., 2013), and in NFT system (Jesus et al., 2011; Silva et al., 2011, 2013).

About above ground dry matter, there was difference between cultivars for S1 and S3, with Cultivada being 42.28\% superior compared to Folha Larga, in standard nutritive solution. On the other side, over saline conditions and with addition of $50 \%$ of $\mathrm{KNO}_{3}(\mathrm{~S} 3)$, Folha Larga was $71.57 \%$ superior, indicating positive effect of potassium nitrate as a strategy for cultivation in saline stress for this cultivar (Figure $2 \mathrm{~B}$ ).

These results emphasize that dry matter is highly influenced by salinity. However, with increment of extra nutrients on nutritive solution $\left(\mathrm{KNO}_{3}\right.$, in the present study) may reduce harmful effects of saline stress, modifying response of cultivars to salinity.

On the effect of nutritive solution on above ground dry matter, it is verified that both cultivar presented reduction in this variable on saline conditions, with 60.86 and $44.71 \%$ of reduction in Cultivada and Folha Larga, respectively. It was also verified that the enrichment of saline nutritive solution with $50 \% \mathrm{of}_{\mathrm{KNO}}(\mathrm{S} 3)$ promoted an increase of $28.67 \%$ in above ground dry matter for Folha Larga cultivar, compared to standard solution (S1) (Figure 2B).

Loss of dry matter was also observed by other authors in arucula crop cultivated in semi-hydroponic system (Santos et al., 2012; Oliveira et al., 2013; Souza Neta et al., 2013).
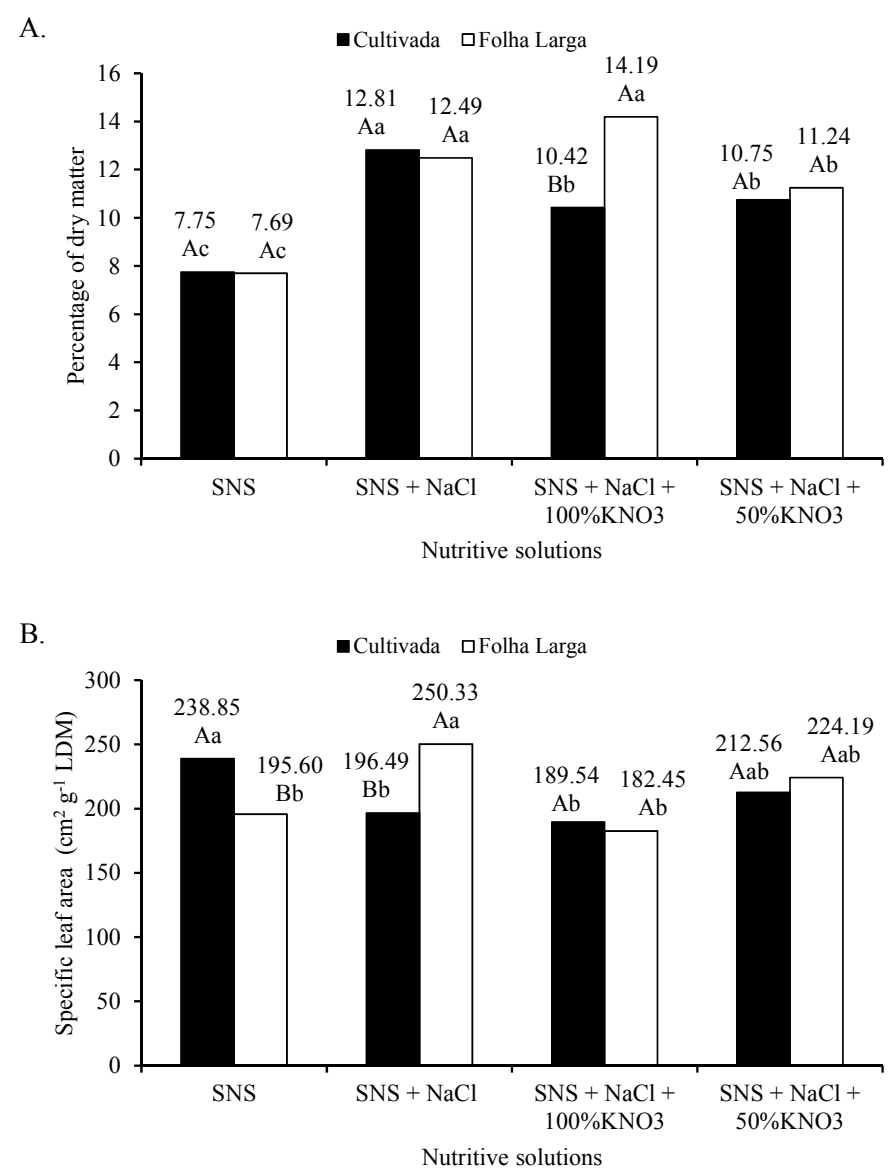

Figure 3. Percentage of dry matter (A) e specific foliar area (B) in arucula cultivars fertigated with saline nutritive solution and potassium nitrate [Averages followed by same letter, upper case (cultivars) and lower case (nutritive solutions) did not differ from each other by Tukey test at 5\% of probability] 
Decrease in dry matter production is strongly linked to the osmotic effect of salinity, what may cause buildup of solutes inside cell and limit photosynthetic activity and, consequently, plants production of dry matter (Parida \& Das, 2005). Moreover, another important point is the ionic unbalance caused by excessive $\mathrm{Na}^{+}$and $\mathrm{Cl}^{-}$ions due to inadequate management of nutrients (Tester \& Davenport, 2003). This effect was verified by Schiattone et al. (2017) studying wild arucula (brassicaceae) and salinity in hydroponic system in Greece.

Cultivars significantly differ for percentage of dry matter only when plants were fertigated with nutrient solution and enriched with $50 \%$ of $\mathrm{KNO}_{3}$ (S3), where Folha Larga was $36.08 \%$ superior (Figure $3 \mathrm{~A}$ ).

The use of saline water in nutritive solution preparation resulted in increase of percentage dry matter in cultivars, promoting and increase of 65.29 and $62.42 \%$ in Cultivada and Folha Larga, respectively. However, for Cultivada there was a reduction of salinity effect on this variable when added $\mathrm{KNO}_{3}$ in saline nutritive solution, in a way that solution S3 and S4 showed reduction of 18.66 and $16.08 \%$, respectively, when compared to percentage of dry matter of solution S2 (Figure 3A).

On the other side, the use of saline solution (S2) enriched with $50 \%$ of $\mathrm{KNO}_{3}(\mathrm{~S} 3)$ promoted increases of 62.42 and $84.39 \%$, respectively, in above ground dry matter content compared to solution S2. However, the enrichment with $100 \%$ of $\mathrm{KNO}_{3}$ reduced values in this variable (Figure $3 \mathrm{~A}$ ).

Percentage of dry matter reflects how much of total mass was transformed in dry matter. This way, the lower the ratio the more plant can absorb water in its tissue related to dry matter. While the greater this value, more efficient plant in producing matter. In proportional terms, with increase in salinity of nutritive solutions plants were more efficient in dry matter production, evidencing lower water content compared to standard solution. This occurs because in saline environment plants tend to lose water due to osmotic pressure. In addition, salts may build up in apoplast and dehydrate cells (Munns \& Tester, 2008).

Increase in dry matter content of arucula may be a benefic alteration caused by salinity, specially related to storage, what was also observed by Barbieri et al. (2011), reporting increase in percentage of dry matter, visual appearance, carotenoids, and phenols when used saline nutritive solution $\left(5 \mathrm{dS} \mathrm{m}^{-1}\right)$. According to Hamilton and Fonseca (2010), the increase of nutritive solution up to $7.5 \mathrm{dS} \mathrm{m}^{-1}$ helped to increase ascorbic acid build up and phenols in arucula.

Cultivars statistically differ in specific leaf area for solutions S1 and S2. Cultivada cultivar was $22.11 \%$ superior compared to Folha Larga in S1, but was $21.51 \%$ inferior in S2, with no significant difference between cultivars in the others nutritive solutions (Figure 3B).

For the effect of nutritive solution on specific leaf area in each cultivar, it was verified that Cultivada showed decrease in $17.73 \%$ (S2), $20.64 \%$ (S3), and $11.16 \%$ (S4) when salinity was increased, even though it did not statistically differ from standard nutritive solution. For Folha Larga cultivar, the $\mathrm{NaCl}$ addition promoted an increase of $27.98 \%$ in specific foliar area, but reduced with its enrichment with $\mathrm{KNO}_{3}$ in $100 \%$ (Figure 3B).

Results allowed inferring that the effect of specific leaf area reduction was not observed when used potassium nitrate, but $\mathrm{KNO}_{3}$ was less efficient in reducing harmful effects of salinity with increase in leaf blade. However, even though nutritive solution S2 showed results statistically similar to S4, when used only saline nutritive solution (S2) the effects of salinity were greater in dry matter of leaf blade. What may indicate some tolerance of this cultivar to salinity (Figure 3B).

Thus, effects of salinity were more expressive in leaf dry matter for Folha Larga, and in leaf blade expansion for Cultivada, indicating that the second one is more sensible to salinity, since, according to Parida and Das (2005), decrease in leaf expansion is one of the main characteristics of salinity effects.

Specific leaf area is an indicator of leaf thickness. An important variable on crop growth evaluation, comparing dry matter production to expansion of leaf area, and, consequently, with the interception of light and photosynthesis (Gary et al., 1993). Therefore, reduction in SLA is an indicative that the effect of salinity was more expressive on leaf expansion than on phytomass, increasing leaf thickness (Oliveira et al., 2016).

Similar results from this study ware also reported in wild species of arucula (Diplotaxis tenuifolia and D. muralis) and in other species from Brassicasseae botanic family, characterizing as an adaptation strategy to salinity (Vos et al., 2013; Bonasia et al., 2017; Schiattone et al., 2017), resulting in an efficient storage and intern water conservation (Munns \& Tester, 2008).

\section{Conclusion}

Cultivada cultivar is more productive than Folha Larga, but presented higher sensibility to salinity. 
Increase of salinity in water for preparation of nutritive solution negatively affects arucula cultivars' development in semi-hydroponic system.

The use of potassium nitrate reduced the effects of salinity on the Folha Larga's development, but did not inhibit negative effects of salinity in any cultivar.

Growth of arucula, Folha Larga cultivar, using saline water in semi-hydroponic system is feasible with addition of $50 \%$ of $\mathrm{KNO}_{3}$.

\section{References}

Ahmad, I., \& Maathuis, F. J. M. (2014). Cellular and tissue distribution of potassium: Physiological relevance, mechanisms and regulation. Journal of Plant Physiology, 171(9), 708-714. https://doi.org/10.1016/j.jplph. 2013.10.016

Alruwaih, N. A., \& Yaylayan, V. A. (2017). Comparative evaluation of bioactive compounds in lyophilized and tray-dried rocket (Eruca sativa). Journal of Food Processing and Preservation, 41(5). https://doi.org/ 10.1111 /jfpp. 13205

Amorim, H. C., Henz, G. P., \& Mattos, L. M. (2007). Identifcação dos tipos de rúcula comercializados no varejo do Distrito Federal. Boletim de Pesquisa e Desenvolvimento da Embrapa Hortaliças, 34, 1-13.

Barbieri, G., Bottino, A., Di Stasio, E., Vallone, S., \& Maggio, A. (2011). Proline and light as quality enhancers of rocket (Eruca sativa Miller) grown under saline conditions. Scientia Horticulturae, 128(4), 393-400. https://doi.org/10.1016/j.scienta.2011.02.010

Björkman, M., Klingen, I., Birch, A. N. E., Bones, A. M., Bruce, T. J. A., Johansen, T. J., ... Stewart, D. (2011). Phytochemicals of Brassicaceae in plant protection and human health-Influences of climate, environment and agronomic practice. Phytochemistry, 72(7), 538-556. https://doi.org/10.1016/j.phytochem.2011.01.014

Bonasia, A., Lazzizera, C., Elia, A., \& Conversa, G. (2017). Nutritional, Biophysical and Physiological Characteristics of Wild Rocket Genotypes As Affected by Soilless Cultivation System, Salinity Level of Nutrient Solution and Growing Period. Frontiers in Plant Science, 8, 1-15. https://doi.org/10.3389/ fpls.2017.00300

Carmo Filho, F., \& Oliveira, O. F. (1995). Mossoró: Um município do semi-árido nordestino, caracterização climática e aspecto floristico (p. 62). Mossoró, RN: ESAM. Coleção Mossoroense, Série B.

Cavarianni, R. L., Cecílio Filho, A. B., Cazetta, J. O., May, A., \& Corradi, M. M. (2008). Nutrient contents and production of rocket as affected by nitrogen concentrations in the nutritive solution. Sci. Agric. (Piracicaba, Braz), 65(6), 652-658. https://doi.org/10.1590/S0103-90162008000600013

Costa, C. M. F., Seabra Júnior, S., Arruda, G. R., \& Souza, S. B. S. (2011). Desempenho de cultivares de rúcula sob telas de sombreamento e campo aberto. Semina: CiênciasAgrárias, 32(1), 93-102. https://doi.org/ 10.5433/1679-0359.2011v32n1p93

Cova, A. M. W., Freitas, F. T. O., Viana, P. C., Rafael, M. R. S., Neto, A. D. A., \& Soares, T. M. (2017). Content of inorganic solutes in lettuce grown with brackish water in different hydroponic systems. Bras. Eng. Agríc. Ambiental, 21(3), 150-155. https://doi.org/10.1590/1807-1929/agriambi.v21n3p150-155

Dias, N. S., Jales, A. G. O., Sousa Neto, O. N., Gonzaga, M. I. S., Queiroz, I. S. R., \& Porto, M. A. F. (2011). Uso de rejeito da dessalinização na solução nutritiva da alface, cultivada em fibra de coco. Revista Ceres, 58(5), 632-637. https://doi.org/10.1590/S0034-737X2011000500014

Favell, D. J. (1998). A comparison of the vitamin C content of fresh and frozen vegetables. Food Chemistry, 62(1), 59-64. https://doi.org/10.1016/S0308-8146(97)00165-9

Ferreira, D. F. (2014). Sisvar: A guide for its bootstrap procedures in multiple comparisons. Ciencia $E$ Agrotecnologia, 38(2), 109-112. https://doi.org/10.1590/S1413-70542014000200001

Furlani, P. R., Silveira, L. C. P., Bolonhezi, D., \& Faquin, V. (1999). Cultivo hidropônico de plantas (p. 52, BoletimTécnico, 180). Campinas: Instituto Agronômico.

Gary, C., Jones, J. W., \& Longuenesse, J. J. (1993) Modeling daily changes in specific leaf area of tomato: The contribution of the leaf assimilate pool. Acta Horticulturae, 328, 205-210. https://doi.org/10.17660/ ActaHortic.1993.328.19 
Grangeiro, L. C., Oliveira, F., Negreiros, M., Marrocos, S., Lucena, R., \& Oliveira, R. (2011). Crescimento e acúmulo de nutrientes em coentro e rúcula. Revista Brasileira de Ciências Agrárias, 6(1), 11-16. https://doi.org/10.5039/agraria.v6ila634

Hamilton, J. M., \& Fonseca, J. M. (2010). Effect of saline irrigation water on antioxidants in three hydroponically grown leafy vegetables: Diplotaxis tenuifolia, Eruca sativa, and Lepidium sativum. HortScience, 45(4), 546-552.

Jesus, C. G. (2011). Estresse salino em rúcula (Eruca sativa Mill.) hidropônica: Aspectos fisiológicos, bioquímicos e nutricionais (Master dissertation, UFRPE, Recife, Brasil). Retrieved from http://www.tede2. ufrpe.br:8080/tede/handle/tede2/5575

Jesus, G. G., Silva Júnior, F. J., Camara, T. R., Silva, E. F. F., \& Willadino, L. (2015). Production of rocket under salt stress in hydroponic systems. Horticultura Brasileira, 33(4), 493-497. https://doi.org/10.1590/S0102053620150000400014

Kerbauy, G. B. (2004). Fisiologia vegetal. Rio de Janeiro, RJ: Guanabara Koogan.

Koukounaras, A., Siomos, A. S., \& Sfakiotakis, E. (2007). Postharvest $\mathrm{CO}_{2}$ and ethylene production and quality of rocket (Eruca sativa Mill.) leaves as affected by leaf age and storage temperature. Postharvest Biology and Technology, 46(2), 167-173. https://doi.org/10.1016/j.postharvbio.2007.04.007

Ku, K. M., Kim, M. J., Jeffery, E. H., Kang, Y. H., \& Juvik, J. A. (2016). Profiles of Glucosinolates, Their Hydrolysis Products, and Quinone Reductase Inducing Activity from 39 Arugula (Eruca sativa Mill.) Accessions. Journal of Agricultural and Food Chemistry, 64(34), 6524-6532. https://doi.org/10.1021/ acs.jafc.6b02750

Luz, Q. M. J., Costa, C. C., \& Guerra, P. M. G. (2011). Efeito da variação da solução nutritiva no cultivo hidropônico de rúcula. Revista Verde, 6(3), 76-82.

Maathuis, F. J. M., \& Sanders, D. (1996). Mechanisms of potassium absorption by higher plant roots. Physiologia Plantarum, 96(1), 158-168. https://doi.org/10.1034/j.1399-3054.1996.960123.x

Machado, F. F., Novack, M. M. E., Nörnberg, J. L., \& Colpo, E. (2011). Análise de frações de fibra alimentar em rúcula ealface em diferentes estágios de maturação, sob sistemahidropônico. Alimentos e Nutrição, 3(2), 401-406.

Maia, S. S. S., Silva, R. C. P. da, Oliveira, F. A. de, Silva, O. M. P. da, Silva, A. C. da, \& Candido, W. S. (2017). Responses of basil cultivars to irrigation water salinity. Bras. Eng. Agríc. Ambiental, 21(11), 44-49. https://doi.org/10.1590/1807-1929/agriambi.v21n1p44-49

Miller, G., Suzuki, N., Ciftci-Yilmaz, S., \& Mittler, R. (2009). Reactive oxygen species homeostasis and signalling during drought and salinity stresses. Plant, Cell and Environment, 33(4), 453-467. https://doi.org/ $10.1111 / \mathrm{j} .1365-3040.2009 .02041 . \mathrm{x}$

Minami, K., \& Tessarioli Neto, J. (1998) A cultura da rúcula. Piracicaba, SP: Escola Superior de Agricultura "Luiz de Queiroz", Universidade de São Paulo.

Morales, M., \& Janick, J. (2002). Arugula: A promising specialty leaf vegetable. In J. Janick, \& A. Whipkey (Eds.), Trends in new crops and new uses (pp. 418-423). ASHS Press, Alexandria, VA.

Munns, R. (2005). Genes and salt tolerance: Bringing them together. New Phytologist, 167, 645-663. https://doi.org/10.1111/j.1469-8137.2005.01487.x

Munns, R., \& Tester, M. (2008). Mechanisms of Salinity Tolerance. Annual Review of Plant Biology, 59(1), 651-681. https://doi.org/10.1146/annurev.arplant.59.032607.092911

Nascimento, M. V., Silva Junior, R. L., Fernandes, L. R., Xavier, R. C., Benett, K. S. S., Seleguini, A., \& Benett, C. G. S. (2017). Manejo da adubação nitrogenada nas culturas de alface, repolho e salsa. Revista de Agricultura Neotropical, 4(1), 65-71.

Nunes, R. L. C., Dias, N. S., Moura, K. K. C. F., Sousa Neto, O. N., \& Costa, J. M. (2013). Efeitos da salinidade da solução nutritiva na produção de pimentão cultivado em substrato de fibra de coco. Revista Caatinga, 26(4), 48-53.

Oliveira, F. A., Medeiros, J. F., Cunha, R. C., Souza, M. W. L., \& Lima L. A. (2016) Uso de bioestimulante como agente amenizador do estresse salino na cultura do milho pipoca. Revista Ciência Agronômica, 47(2), 307-315. 
Oliveira, F. A., Souza Neta, M. L., Silva, R. T., Souza, A. A. T., Oliveira, M. K. T., \& Medeiros, J. F. (2013). Desempenho de cultivares de rúcula sob soluções nutritivas com diferentes salinidades. Agro@mbiente On-line, 7(2), 170-178. https://doi.org/10.18227/1982-8470ragro.v7i2.940

Parida, A. K., \& Das, A. B. (2005). Salt tolerance and salinity effects on plants: A review. Ecotoxicology and Environmental Safety, 60(3), 324-349. https://doi.org/10.1016/j.ecoenv.2004.06.010

Parihar, P., Singh, S., Singh, R., Singh, V. P., \& Prasad, S. M. (2015). Effect of salinity stress on plants and its tolerance strategies: A review. Environmental Science and Pollution Research, 22(6), 4056-4075. https://doi.org/10.1007/s11356-014-3739-1

Paulus, D., Paulus, E., Nava, G. A., \& Moura, C. A. (2012). Crescimento, consumo hídrico e composição mineral de alface cultivada em hidroponia com águas salinas. Revista Ceres, 59(1), 110-117. https://doi.org/10.1590/S0034-737X2012000100016

Pérez-López, U., Miranda-Apodaca, J., Lacuesta, M., Mena-Petite, A., \& Muñoz-Rueda, A. (2015). Growth and nutritional quality improvement in two differently pigmented lettuce cultivars grown under elevated $\mathrm{CO}_{2}$ and/or salinity. Scientia Horticulturae, 195, 56-66. https://doi.org/10.1016/j.scienta.2015.08.034

Podsedek, A. (2007). Natural antioxidants and antioxidant capacity of Brassica vegetables: A review. LWT-Food Science and Technology, 40(1), 1-11. https://doi.org/10.1016/j.lwt.2005.07.023

Prado, R. M. (2008). Absorção Iônica Radicular: Fatores internos e externos que afeta a absorção de nutrientes pela raiz. In R. M. Prado (Ed.), Nutrição de Plantas. São Paulo, SP: UNESP.

Santos, R. S. da S., Dias, N. da S., Duarte, S. N., \& Lima, C. J. G. de S. (2012). Uso de águas salobras na produção de rúcula cultivada em substrato de fibra de coco1. Revista Caatinga, 25(1), 113-118.

Schiattone, M. I., Candido, V., Cantore, V., Montesano, F. F., \& Boari, F. (2017). Water use and crop performance of two wild rocket genotypes under salinity conditions. Agricultural Water Management, 194, 214-221. https://doi.org/10.1016/j.agwat.2017.09.009

Shannon, M. C., \& Grieve, C. M. (1998). Tolerance of vegetable crops to salinity. Scientia Horticulturae, 78(1-4), 5-38. https://doi.org/10.1016/S0304-4238(98)00189-7

Silva, A. O. da, Silva, D. J. R. da, Soares, T. M., Ênio, Ê. F., Dos Santos, A. N., \& Rolim, M. M. (2011). Produção de rúcula em sistema hidropônico NFT utilizando água salina do Semiárido-PE e rejeito de dessalinizador. Revista Brasileirade Ciencias Agrarias, 6(1), 147-155. https://doi.org/10.5039/agraria. v6i1a929

Silva, F. V., Duarte, S. N., Santos, R. S. S., \& Medeiros, P. R. F. (2013). Cultivo hidropônico de rúcula utilizando solução nutritiva salina. Revista Brasileira de Ciências Agrárias, 8(3), 476-482. https://doi.org/ 10.5039/agraria.v8i3a1689

Souza Neta, M. L., Oliveira, F. A., Silva, R. T., Souza, A. A. T., Oliveira, M. K. T., \& Medeiros, J. F. (2013). Efeitos da salinidade sobre o desenvolvimento de rúcula cultivada em diferentes substratos hidropônicos. RevistaAgro@mbiente, 7(2),154-161.https://doi.org/10.18227/1982-8470ragro.v7i2.947

Taiz, L., \& Zeiger, E. (2013). Fisiologia vegetal. Porto Alegre, RS: Artmed.

Tavakkoli, E., Fatehi, F., Coventry, S., Rengasamy, P., \& McDonald, G. K. (2011). Additive effects of $\mathrm{Na}^{+}$and $\mathrm{Cl}^{-}$ions on barley growth under salinity stress. Journal of Experimental Botany, 62(6), 2189-2203. https://doi.org/10.1093/jxb/erq422

Tester, M., \& Daven port, R. (2003). $\mathrm{Na}^{+}$Tolerance and $\mathrm{Na}^{+}$Transport in Higher Plants. Annals of Botany, 91(5), 503-527. https://doi.org/10.1093/aob/mcg058

Vos, A. C., Broekman, R., Almeida Guerra, C. C., Rijsselberghe, M. V., \& Rozema, J. (2013). Developing and testing new halophyte crops: A case study of salt tolerance of two species of the Brassicaceae, Diplotaxis tenuifolia and Cochlearia officinalis. Environmental and Experimental Botany, 92, 154-164. https://doi.org/10.1016/j.envexpbot.2012.08.003

\section{Copyrights}

Copyright for this article is retained by the author(s), with first publication rights granted to the journal.

This is an open-access article distributed under the terms and conditions of the Creative Commons Attribution license (http://creativecommons.org/licenses/by/4.0/). 